\title{
Dental caries status and trend in 5-, 7- and 12-year-old children from the Małopolskie region in comparison to the Polish population
}

Department of Paedodontics, Institute of Dentistry, Jagiellonian University Medical College, Cracow Head of Department: Anna Jurczak, MD, PhD

\section{KEYWORDS}

dental caries, epidemiological studies, DMFT, dmft

\begin{abstract}
SUMMARY
Introduction. In 2016, 5-, 7- and 12-year-old children from the Małopolskie region were included in the study of oral health as part of the Nationwide Monitoring of Oral Health programme, which has been periodically implemented in selected index groups of the Polish population since 1997.

Aim. To evaluate the prevalence and level of dental caries in 5-, 7- and 12-year-old children from the Małopolskie region and to observe the dental caries trend in this region in recent years in relation to the Polish population.

Material and methods. The study covered 673 children from the Małopolskie region, including 223 aged 5, 225 aged 7 and 225 aged 12 years. Dental condition/state of dentition was examined according to the WHO recommendations and criteria. The prevalence and level of dental caries in children from the Małopolskie region were evaluated and compared with the results of earlier studies from this province. The obtained results were also compared with the results for the entire Polish population from the current and previous nationwide monitoring studies. The studies were conducted upon the consent of the Medical University of Warsaw Ethics Committee no. KB 190/2016.

Results. Dental caries prevalence in 5-, 7- and 12-year-old children from the Małopolskie region that were covered by the study was $74.9,84.9$ and $81.8 \%$, respectively. The average values of $\mathrm{dmft}$ were 4.55 (in the age group of 5) and 5.38 (in the age group of 7), while DMFT for particular age groups was $0.03,0.56$ and 3.54 , respectively. Slight decrease in the value of these indications of caries is noticed for 5- and 7-year-old children from the Małopolskie region (decrease in prevalence by 2.5 and $6.7 \%$, respectively, as well as a fall in the value of $\mathrm{dmft}$ by 0.71 in the age group of 5 , relative to 2011). The group of 12 -year-old children from our region, as the only one from the entire Polish population of children of this age, have kept a downward trend of caries prevalence (a fall by $12.7 \%$ relative to the monitoring study from 2010). This reduction needs to be confirmed in the next monitoring studies.

Conclusions. The presented results indicate stable high prevalence of dental caries in children of the Małopolskie region and in the whole country. It is therefore necessary to enhance actions intended to improve this situation through education of both children and their parents, widespread prophylaxis, and greater health-oriented awareness of patients.
\end{abstract}

\section{INTRODUCTION}

Dental caries is one of the most common diseases of the oral cavity $(1,2)$. It is also the most common chronic disease of childhood (3-5). It is considered a social disease based on its prevalence, severity and treatment costs (1).
According to WHO dental caries is a local pathological process leading to the decalcification of enamel and dentin, disintegration of hard dental tissues and the resultant cavity (2). It is a multi-factor disease caused by the coexistence and influence of plaque and carbohydrates supplied with food on vulnerable dental tissues for some 
time $(1,2)$. Dental caries is considered to be the result of imbalance of alternating dynamic physiological processes of demineralisation and remineralisation. The predominance of demineralisation leads to the loss of mineral substances, although the process is reversible until a cavity develops $(1,2)$.

The initiation and progression of dental caries is dependent to a large extent on sociomedical and behavioural factors (socioeconomic conditions, knowledge on caries prevention and healthy behaviour) $(1,2)$.

The complaints associated with an untreated caries process and the resultant complications affect the general health and quality of life of patients at any age (1). Pain and complications of caries in children can cause sleep disturbances, difficulties chewing food and gastrointestinal disorders leading to a low BMI (6-10). Tooth loss resulting from the lack of treatment of caries in children and adolescents can also lead to speech impairment, chewing difficulties as well as malocclusion and abnormal development of the stomatognathic system.

Consequently, as expected, clear recommendations have been issued by international institutions and organisations regarding the need for the assessment of public health systems, the development of oral health monitoring systems as well as efficacy of health promotion and oral health prevention programmes (11-16). This is achieved by epidemiological studies of oral health status conducted in accordance with the principles adopted by the World Health Organization (WHO) and through WHO health goals for a given year. Such actions have contributed to the improvement of oral health in many countries. Over nearly 20 years, starting from 1981, when WHO and FDI proposed oral health goals to be achieved by $2000,70 \%$ of countries managed to achieve them. This means, for example, that $85 \%$ of the world population of 12 -year-olds (a group which is most frequently studied and compared) had no more than 3 teeth affected with caries. Poland, together with Bulgaria, Hungary, Latvia and Lithuania was in a group of countries whose mean DMFT value was larger than 3 . It was 3.8 in Poland and only $48.9 \%$ of children had a DMFT of $\leq 3(11,17-22)$.

Epidemiological studies based on WHO criteria have been conducted in Poland since 1987. In 1987-1995 they were part of a Ministry of Health statutory programme. The Nationwide Monitoring of Oral Health programme, commissioned by the Ministry of Health, has been conducted periodically since 1997 . The programme studies the factors affecting oral health among the so-called index age groups in the population. These groups and the intervals between the studies were selected based on the physiological changes in the stomatognathic system and age-related changes of caries dynamics $(1,11,18)$.

As the results of these studies show, over 27 years (up to 2014 inclusive) a small downward trend was observed in Poland regarding both caries prevalence and its severity expressed with dmft and DMFT indices. However, the values of these indices are still disturbingly high, particularly when compared with the data from other European countries $(18,23-28)$. Thus, they indicate a persistently high incidence of caries in children in Poland and the need for more intensive action to improve the situation.

\section{Aim}

The aim of the study is to evaluate the prevalence and severity of caries expressed as the mean dmft index for deciduous teeth and DMFT for permanent teeth in 5-, 7- and 12-year-old children from the province of Małopolskie, Poland, and to observe the trend of caries disease in this province in recent years relative to the Polish population.

\section{Material AND METHODS}

In the Małopolskie province, the Nationwide Monitoring of Oral Health study of 2016 covered 673 children, including 223 individuals aged 5 years (116 from urban and 107 from rural areas, 110 girls and 113 boys), 225 aged 7 years (131 from urban, 94 from rural areas, 106 girls and 119 boys) and 225 aged 12 years ( 121 from urban and 104 from rural areas, 118 girls and 107 boys).

The children's state of dentition was examined according to WHO recommendations and criteria (29). Clinical examination was conducted using a diagnostic mirror and a WHO probe in artificial light. The presence of cavities in deciduous and permanent teeth as well as the number of teeth removed due to caries and restored teeth were recorded, among other aspects. An additional socio-medical study was conducted using a questionnaire recommended by WHO which was supplemented with questions assessing sociodemographic factors.

The studies were conducted upon the consent of the Medical University of Warsaw Ethics Committee no. KB $190 / 2016$. Statistical analysis of the obtained results was performed using $\mathrm{R}$ software, version 3.4.0. Qualitative variables were compared between groups using the chi-square test (with Yates' correction) or the Fisher's exact test for low expected numbers in the tables. Quantitative variables were compared in two groups using the Student's t-test (for a normal distribution of a variable in the groups under analysis) or the Mann-Whitney's test (for a variable with a non-normal distribution). Data variability was evaluated using the standard deviation (SD). Normality of the variable distribution was tested using the Shapiro-Wilk test. A level of significance of 0.05 was adopted for analysis, therefore, all $p$ values below 0.05 were interpreted as significant relationships.

\section{RESUltS}

The prevalence of caries in the group of 5-year-olds was $74.9 \%$ with children in urban and rural areas as well as boys and girls achieving a similar result. In the group 
of 7-year-olds caries was present in 191 children, which accounts for $84.9 \%$ of the subjects. Caries prevalence was similar between cities and the country as well as between boys and girls (tab. 1).

In the group of 12 -year-olds 184 children $(81.8 \%$ of the subjects) were affected by caries. It was the lowest figure in this age group among all provinces included in the studied population. A statistically significant higher prevalence was observed in girls: $87.3 \%$ (vs. $75.7 \%$ for boys) and in the inhabitants of rural areas: $92.31 \%$ (vs. $72.7 \%$ for children living in cities) (tab. 1).

The severity of caries in the Małopolskie province was determined using mean dmft and DMFT indices (tab. 2). In the group of 5-year-olds the mean value of $\mathrm{dmft} \pm \mathrm{SD}$ was $4.55 \pm 4.16$. The main component of the $\mathrm{dmft}$ index was the number of decayed deciduous teeth (mean $\mathrm{dt} \pm \mathrm{SD}$ $=4.03 \pm 4.04$ ). No statistically significant differences between dmft values for urban and rural areas and for girls and boys have been observed (tab. 3). However, what is worthy of note is the higher values for decayed teeth (dt) in boys $(4.27 \pm 4.23)$ and inhabitants of rural areas (4.21 $\pm 4.05)$ in comparison with girls $(3.77 \pm 3.83)$ and urban dwellers (3.86 \pm 4.03 ) (tab. 3).

The mean DMFT value in the group of 5-year-olds (mean \pm SD) was $0.03 \pm 0.17$ (tab. 2). The only DMFT component was the number of decayed teeth (DT) for the whole study group: $0.03 \pm 0.17$. The mean values of DMFT components for children living in the country and for boys were higher compared to DMFT for children living in cities and for girls. However, these differences were not statistically significant. Permanent tooth decay in 5-year-olds affected exclusively their first molars (tab. 4).

All children aged 7 had a mixed dentition (they had at least one permanent tooth). The mean number of deciduous teeth in the oral cavity was $13.82 \pm 2.27$ and that of permanent teeth was $9.23 \pm 2.55$.

The mean dmft value in 7-year-olds in the Małopolskie province was $5.38 \pm 3.73$ (tab. 2). The main component of the dmft index was the number of decayed deciduous teeth (dt) (tab. 3).

The value of the dt component (the number of deciduous teeth with cavities) was statistically significantly higher

Tab. 1. Prevalence of caries in 5-, 7- and 12-year-old children by gender and place of residence. The results of the current monitoring study of 2016 (1)

\begin{tabular}{|c|c|c|c|c|c|c|c|c|c|}
\hline & \multicolumn{2}{|c|}{ 5-year-olds } & \multirow{2}{*}{$p^{*}$} & \multicolumn{2}{|c|}{ 7-year-olds } & \multirow{2}{*}{$p^{*}$} & \multicolumn{2}{|c|}{ 12-year-olds } & \multirow{2}{*}{$p^{*}$} \\
\hline & $\mathbf{n}$ & $\%$ & & $\mathbf{n}$ & $\%$ & & $\mathbf{n}$ & $\%$ & \\
\hline Girls & 79 & $71.82 \%$ & \multirow{2}{*}{0.374} & 89 & $83.96 \%$ & \multirow{2}{*}{0.857} & 103 & $87.29 \%$ & \multirow{2}{*}{0.038} \\
\hline Boys & 88 & $77.88 \%$ & & 102 & $85.71 \%$ & & 81 & $75.70 \%$ & \\
\hline City & 87 & $75.00 \%$ & \multirow{2}{*}{0.999} & 109 & $83.21 \%$ & \multirow{2}{*}{0.52} & 88 & $72.73 \%$ & \multirow{2}{*}{$<0.001$} \\
\hline Country & 80 & $74.77 \%$ & & 82 & $87.23 \%$ & & 96 & $92.31 \%$ & \\
\hline
\end{tabular}

${ }^{*}$ Chi-square test. Statistical significance of differences for $\mathrm{p}<0.05$

Tab. 2. The values of dmft and DMFT for 5- and 7-year-olds and DMFT for 12-year-olds. The results of the current monitoring study of 2016 (1). The analysis was conducted using the Mann-Whitney test

\begin{tabular}{|c|c|c|c|c|c|c|c|c|c|}
\hline \multirow{2}{*}{ Index } & \multicolumn{3}{|c|}{ 5-year-olds } & \multicolumn{3}{|c|}{ 7-year-olds } & \multicolumn{3}{|c|}{ 12-year-olds } \\
\hline & $\mathbf{N}$ & mean & SD & $\mathbf{N}$ & mean & SD & $\mathbf{N}$ & mean & SD \\
\hline $\mathrm{dt}$ & 223 & 4.03 & 4.04 & 225 & 4.57 & 3.57 & & & \\
\hline $\mathrm{mt}$ & 223 & 0.02 & 0.18 & 225 & 0.12 & 0.64 & & & \\
\hline $\mathrm{ft}$ & 223 & 0.5 & 1.24 & 225 & 0.68 & 1.33 & & & \\
\hline $\mathrm{dmft}$ & 223 & 4.55 & 4.16 & 225 & 5.38 & 3.73 & & & \\
\hline $\mathrm{DT}$ & 223 & 0.03 & 0.17 & 225 & 0.3 & 0.75 & 225 & 1.64 & 1.97 \\
\hline $\mathrm{MT}$ & 223 & 0 & 0 & 225 & 0 & 0 & 225 & 0.03 & 0.22 \\
\hline $\mathrm{FT}$ & 223 & 0 & 0 & 225 & 0.26 & 0.77 & 225 & 1.88 & 2.15 \\
\hline DMFT & 223 & 0.03 & 0.17 & 225 & 0.56 & 1.11 & 225 & 3.54 & 2.92 \\
\hline
\end{tabular}


Tab. 3. The values of $\mathrm{dmft}$ and the $\mathrm{dt}, \mathrm{mt}$, $\mathrm{ft}$ components by gender and place of residence for 5 - and 7-year-olds. The results of the current monitoring study of 2016 (1)

\begin{tabular}{|c|c|c|c|c|c|c|c|c|c|}
\hline & & \multicolumn{3}{|c|}{ 5-year-olds } & \multirow{2}{*}{$p^{\star}$} & \multicolumn{3}{|c|}{ 7-year-olds } & \multirow{2}{*}{$p^{*}$} \\
\hline & & $\mathbf{N}$ & mean & SD & & $\mathbf{N}$ & mean & SD & \\
\hline \multirow{2}{*}{$\mathrm{dmft}$} & Girls & 110 & 4.2 & 4.04 & \multirow{2}{*}{0.215} & 106 & 5.05 & 3.52 & \multirow{2}{*}{0.344} \\
\hline & Boys & 113 & 4.88 & 4.27 & & 119 & 5.67 & 3.89 & \\
\hline \multirow{2}{*}{$\mathrm{dmft}$} & City & 116 & 4.46 & 4.22 & \multirow{2}{*}{0.667} & 131 & 4.98 & 3.65 & \multirow{2}{*}{0.069} \\
\hline & Country & 107 & 4.64 & 4.11 & & 94 & 5.93 & 3.78 & \\
\hline \multirow{2}{*}{$\mathrm{dt}$} & Girls & 110 & 3.77 & 3.83 & \multirow{2}{*}{0.448} & 106 & 4.32 & 3.42 & \multirow{2}{*}{0.435} \\
\hline & Boys & 113 & 4.27 & 4.23 & & 119 & 4.79 & 3.69 & \\
\hline \multirow{2}{*}{$\mathrm{mt}$} & Girls & 110 & 0.02 & 0.19 & \multirow{2}{*}{0.336} & 106 & 0.06 & 0.27 & \multirow{2}{*}{0.181} \\
\hline & Boys & 113 & 0.03 & 0.16 & & 119 & 0.18 & 0.84 & \\
\hline \multirow{2}{*}{$\mathrm{ft}$} & Girls & 110 & 0.41 & 1.05 & \multirow{2}{*}{0.506} & 106 & 0.67 & 1.43 & \multirow{2}{*}{0.314} \\
\hline & Boys & 113 & 0.58 & 1.4 & & 119 & 0.7 & 1.24 & \\
\hline \multirow{2}{*}{$\mathrm{dt}$} & City & 116 & 3.86 & 4.03 & \multirow{2}{*}{0.522} & 131 & 4.06 & 3.37 & \multirow{2}{*}{0.016} \\
\hline & Country & 107 & 4.21 & 4.05 & & 94 & 5.28 & 3.74 & \\
\hline \multirow{2}{*}{$\mathrm{mt}$} & City & 116 & 0.02 & 0.13 & \multirow{2}{*}{0.932} & 131 & 0.15 & 0.79 & \multirow{2}{*}{0.883} \\
\hline & Country & 107 & 0.03 & 0.22 & & 94 & 0.1 & 0.36 & \\
\hline \multirow{2}{*}{$\mathrm{ft}$} & City & 116 & 0.58 & 1.42 & \multirow{2}{*}{0.344} & 131 & 0.78 & 1.32 & \multirow{2}{*}{0.052} \\
\hline & Country & 107 & 0.41 & 1.02 & & 94 & 0.55 & 1.34 & \\
\hline
\end{tabular}

*Mann-Whitney test

in 7-year-olds from rural areas than that of 7-year-olds in urban areas; at the same time, the $\mathrm{ft}$ component (the number of filled deciduous teeth) was lower. The value of pt in rural areas in the Małopolskie province was the highest in the whole studied population of 4 provinces. The mean dmft index and $\mathrm{dt}$ and $\mathrm{mt}$ components were slightly higher in boys than in girls (tab. 3).

In $7.1 \%$ of 7-year-olds the lack of at least one deciduous tooth was found $(m t>0)$. The proportion of subjects with at least one filled deciduous tooth was $28.4 \%$, which was associated with statistically significantly lower figures of $\mathrm{ft}>0$ in comparison with the whole studied national population.

The mean value of DMFT for permanent teeth was $0.56 \pm 1.11$ in the whole population of 7-year-olds (tab. 2). The mean component values for the whole population of children from the Małopolskie region and those with at least one erupted permanent tooth were the same. Children from rural areas had statistically significantly higher DMFT values: $0.79 \pm 1.28$ (tab. 4).

The mean DT value was higher in boys $(0.39 \pm 0.85)$ in comparison with girls $(0.21 \pm 0.61)$, but the difference was not statistically significant. A similar relationship was observed for the FT component, while no permanent teeth missing due to caries were observed $(\mathrm{MT}=0)$. The DT component was significantly higher for country dwellers $(0.48 \pm 0.91)$ in comparison with children living in cities $(0.18 \pm 0.59)$ (tab. 4$)$.

In the group of 12-year-olds from the Małopolskie province the mean DMFT value was $3.54 \pm 2.92$ (tab. 2). The main component of DMFT was the number of decayed teeth; however, the difference between DT and FT was small. The mean values of DMFT index components are presented in table 2 .

A higher mean DMFT value was observed in the country (DMFT $=4.27 \pm 2.96)$ than in the city $(2.92 \pm$ 2.76). Slightly higher values were found in girls (DMFT $=3.77 \pm 2.87)$ than in boys $(3.29 \pm 2.97)$. The severity of caries in 12-year-olds living in rural areas was statistically significantly higher than in those living in urban areas (tab. 4).

The analysis of DMFT components demonstrated that the higher value of this index in rural areas was due to a statistically significantly higher DT component, which reached $2.15 \pm 2.14$, while for urban areas DT was 1.19 \pm 1.69 . The level of the different DMFT components was 
Dental caries status and trend in 5-, 7- and 12-year-old children from the Małopolskie region in comparison to the Polish...

Tab. 4. The values of DMFT and the DT, MT, FT components by gender and place of residence for 5-, 7- and 12-year-olds. The results of the current monitoring study of 2016 (1). (U for all 5-year-olds $W=0$ and $U=0$. Therefore, $D M F=D)$

\begin{tabular}{|c|c|c|c|c|c|c|c|c|c|c|c|c|c|}
\hline & & \multicolumn{3}{|c|}{ DMFT for 5-year-olds } & \multirow{2}{*}{$p^{*}$} & \multicolumn{3}{|c|}{ DMFT for 7-year-olds } & \multirow{2}{*}{$p^{*}$} & \multicolumn{3}{|c|}{ DMFT for 12-year-olds } & \multirow{2}{*}{$p^{*}$} \\
\hline & & $\mathbf{N}$ & mean & SD & & $\mathbf{N}$ & mean & SD & & $\mathbf{N}$ & mean & SD & \\
\hline \multirow{2}{*}{ DMFT } & Girls & 110 & 0.02 & 0.13 & \multirow{2}{*}{0.267} & 106 & 0.39 & 0.9 & \multirow{2}{*}{0.059} & 118 & 3.77 & 2.87 & \multirow{2}{*}{0.148} \\
\hline & Boys & 113 & 0.04 & 0.21 & & 119 & 0.72 & 1.25 & & 107 & 3.29 & 2.97 & \\
\hline \multirow{2}{*}{ DMFT } & City & 116 & 0.02 & 0.13 & \multirow{2}{*}{0.209} & 131 & 0.4 & 0.95 & \multirow{2}{*}{0.012} & 121 & 2.92 & 2.76 & \multirow{2}{*}{$<0.001$} \\
\hline & Country & 107 & 0.05 & 0.21 & & 94 & 0.79 & 1.28 & & 104 & 4.27 & 2.96 & \\
\hline \multirow{2}{*}{ DT } & Girls & & & & & 106 & 0.21 & 0.61 & \multirow{2}{*}{0.167} & 118 & 1.59 & 1.9 & \multirow{2}{*}{0.851} \\
\hline & Boys & & & & & 119 & 0.39 & 0.85 & & 107 & 1.68 & 2.05 & \\
\hline \multirow{2}{*}{ MT } & Girls & & & & & 106 & 0 & 0 & \multirow{2}{*}{1} & 118 & 0.03 & 0.22 & \multirow{2}{*}{0.739} \\
\hline & Boys & & & & & 119 & 0 & 0 & & 107 & 0.03 & 0.22 & \\
\hline \multirow{2}{*}{ FT } & Girls & & & & & 106 & 0.18 & 0.64 & \multirow{2}{*}{0.239} & 118 & 2.14 & 2.22 & \multirow{2}{*}{0.022} \\
\hline & Boys & & & & & 119 & 0.34 & 0.87 & & 107 & 1.58 & 2.203 & \\
\hline \multirow{2}{*}{ DT } & City & & & & & 131 & 0.18 & 0.59 & \multirow{2}{*}{0.002} & 121 & 1.19 & 1.69 & \multirow{2}{*}{$<0.001$} \\
\hline & Country & & & & & 94 & 0.48 & 0.91 & & 104 & 2.15 & 2.14 & \\
\hline \multirow{2}{*}{ MT } & City & & & & & 131 & 0 & 0 & \multirow{2}{*}{1} & 121 & 0.02 & 0.13 & \multirow{2}{*}{0.525} \\
\hline & Country & & & & & 94 & 0 & 0 & & 104 & 0.05 & 0.29 & \\
\hline \multirow{2}{*}{ FT } & City & & & & & 131 & 0.23 & 0.72 & \multirow{2}{*}{0.444} & 121 & 1.71 & 2.03 & \multirow{2}{*}{0.188} \\
\hline & Country & & & & & 94 & 0.31 & 0.84 & & 104 & 2.07 & 2.27 & \\
\hline
\end{tabular}

${ }^{*}$ Mann-Whitney test. Statistical significance of differences for $\mathrm{p}<0.05$

similar in girls and in boys. However, the number of filled permanent teeth (FT) was significantly higher in girls (2.14 $\pm 2.22)$ than in boys $(1.58 \pm 2.03)$. The values of the different DMFT components depending on the place of residence and gender are presented in table 4 . The lack of at least one permanent tooth due to caries (MT >0) was found in 5 children (2.2\%). The proportion of 12 -year-olds with at least one filled permanent tooth (WZ >0) was $62.2 \%$ with statistically significantly more such cases among girls than boys. A percentage of children with current dental caries (DT > 0) has been observed to be higher in a statistically significant way among children residing in rural areas compared with 12-year-olds from cities (tab. 5).

The analysis of the results of the present study reveals an increase in the incidence of caries with age among children from the Małopolskie province: from $74.9 \%$ in 5-year-olds to $84.9 \%$ in 7 -year-olds. The severity of caries also increases with age: from 4.70 decayed teeth in 5-year-olds to 5.61 in 7-year-olds. The reduction of the prevalence and severity of caries observed at 12 years of age $(85.4 \%$ and 3.75 decayed teeth, respectively, for the whole studied population and $81.8 \%$ and 3.54 for Małopolskie) is only an apparent improvement associated with dentition replacement (the presence of 25.4 erupted permanent teeth on average which have been sitting in the oral cavity for a relatively short period of time) (2).

\section{Discussion}

In recent years few epidemiological studies on children's dentition have been conducted in the Małopolskie province. Therefore, the results of studies from 2002 onwards have been used to determine the caries trend and make comparisons.

The results of the Nationwide Monitoring of Oral Health study conducted in 2011 demonstrated that caries prevalence for 5-year-old children from the Małopolskie region was $77.4 \%$ and was higher both from the figure for children from the city of Cracow and the nearby areas in a study by Jurczak et al. conducted in 2010-2012 (71.7\%) and from the prevalence determined in the present monitoring study $(2016-74.9 \%)$. Similarly, the highest prevalence of caries in the group of 7-year-olds from Małopolskie was found in the monitoring study of 2011 (91.6\%), while a lower figure was observed in the study conducted in Cracow (73\%) and the monitoring study of 2016 (84.9\%). The prevalence of caries was $94.5 \%$ for 12 -year-old children 
Tab. 5. Numbers and proportions of 12 -year-old children with current decay (DT $>0$ ), at least 1 tooth removed due to decay $($ MT $>0$ ) and at least 1 filled tooth $(\mathrm{FT}>0)$ in the Małopolskie province by gender and place of residence. The results of the current monitoring study of 2016 (1)

\begin{tabular}{|c|c|c|c|c|c|c|}
\hline & & \multicolumn{2}{|c|}{ Girls $(\mathrm{N}=118)$} & \multicolumn{2}{|c|}{ Boys ( $N=107)$} & \multirow{2}{*}{$p^{*}$} \\
\hline & & $\mathbf{n}$ & $\%$ & $\mathbf{n}$ & $\%$ & \\
\hline \multirow[t]{2}{*}{ DT } & $>0$ & 68 & $57.63 \%$ & 63 & $58.88 \%$ & 0.956 \\
\hline & 0 & 50 & $42.37 \%$ & 44 & $41.12 \%$ & \\
\hline \multirow[t]{2}{*}{ MT } & $>0$ & 3 & $2.54 \%$ & 2 & $1.87 \%$ & $1 \mathrm{~F}$ \\
\hline & 0 & 115 & $97.46 \%$ & 105 & $98.13 \%$ & \\
\hline \multirow[t]{4}{*}{ FT } & $>0$ & 83 & $70.34 \%$ & 57 & $53.27 \%$ & 0.012 \\
\hline & 0 & 35 & $29.66 \%$ & 50 & $46.73 \%$ & \\
\hline & & \multicolumn{2}{|c|}{ City $(\mathrm{N}=121)$} & \multicolumn{2}{|c|}{ Country $(N=104)$} & \\
\hline & & $\mathbf{n}$ & $\%$ & $\mathbf{n}$ & $\%$ & $p$ \\
\hline \multirow[t]{2}{*}{ DT } & $>0$ & 60 & $49.59 \%$ & 71 & $68.27 \%$ & 0.007 \\
\hline & 0 & 61 & $50.41 \%$ & 33 & $31.73 \%$ & \\
\hline \multirow[t]{2}{*}{ MT } & $>0$ & 2 & $1.65 \%$ & 3 & $2.88 \%$ & $0.664 \mathrm{~F}$ \\
\hline & 0 & 119 & $98.35 \%$ & 101 & $97.12 \%$ & \\
\hline \multirow[t]{2}{*}{ FT } & $>0$ & 68 & $56.20 \%$ & 72 & $69.23 \%$ & 0.061 \\
\hline & 0 & 53 & $43.80 \%$ & 32 & $30.77 \%$ & \\
\hline
\end{tabular}

${ }^{*}$ Chi-square test; F - Fisher's exact test (low expected numbers in the table). Statistical significance of differences for $\mathrm{p}<0.05$

from the Małopolskie province included in the 2010 nationwide monitoring study. Similar figures are reported by Kwapińska et al. (93.59\%) in 12-year-old children from Cracow schools studied in 2002. Jurczak et al. demonstrated a significantly lower rate of caries in children from this age group: $63.8 \%$, which was also lower in the last study from 2016: $81.8 \%(25,26,30,31)$.

The highest level of caries severity in deciduous teeth of 5-year-old children was noted in the monitoring study of 2011: 5.26; a lower level in 2016: 4.55 and the lowest one in 2010-2012: 4.35. In the group of 7-year-olds from the Małopolskie province the highest $\mathrm{dmft}$ levels were reported in the last monitoring study: 5.38; lower in 2011: 5.26 and much lower in the Cracow study: 3.55 . Jurczak et al. reported the highest DMFT figure in the same age group: 1.64, while lower levels were recorded in the monitoring studies of 2011 and 2016: 0.64 and 0.56, respectively. The severity of caries in permanent teeth of 12-year-olds from Cracow schools was 5.88 in 2002; a slightly lower result was recorded for children from Cracow and the nearby areas studied in 2010-2012 (5.02) and the lowest one for children from the Małopolskie province in the last monitoring study of 2016 (3.54) $(25,26,30,31)$.

The analysis of the results of these epidemiological studies shows that the prevalence of caries in Małopolskie children of all studied age groups has decreased in recent years (more considerable decreases were recorded for 7- and 12-year-olds: from 91.6 to $84.9 \%$ and from 94.5 to $81.8 \%$, respectively). The sufficient number of studies on 12-year-old children has allowed to determine the trend for caries prevalence (fig. 1).

The severity of caries, on the other hand, has remained at a comparable level. However, based on the study by Kwapińska et al. of 2002 on children from Cracow schools, which revealed a caries severity level of 5.88, a decrease in DMFT can be noticed for 12-yearolds in the present monitoring study $(23,30)$ (fig. 2). The different caries figures obtained in the study by Jurczak et al. seem to be caused by the use of a different selection method for the studied population (patients of the Paedodontics Clinic of the University Dental Centre in Cracow were studied) and lower numbers of subjects in the different age groups.

The results of monitoring studies for the population of 5 -year-olds in our country show a decrease in the prevalence of caries from $79.9 \%(2011)$ to $76.8 \%(2016)(1,26)$. Similarly, the severity of caries in this age group has displayed a very slow decrease between 2011 and 2016 (from 5.07 to 4.70 , respectively) $(1,26)$. The prevalence of caries among Polish 7-year-olds in 2016 was 
Dental caries status and trend in 5-, 7- and 12-year-old children from the Małopolskie region in comparison to the Polish...

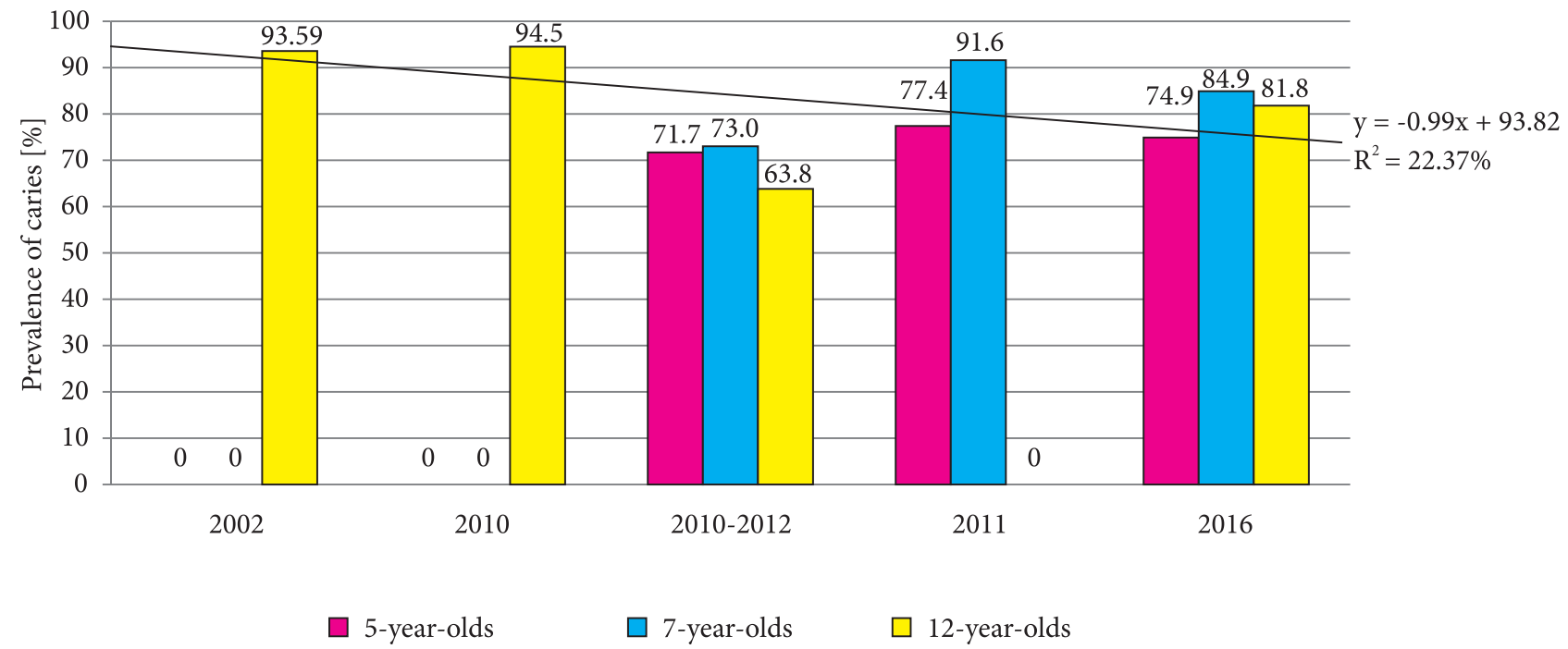

Fig. 1. Prevalence of caries in 5-, 7- and 12-year-old children in consecutive studies in the Małopolskie province

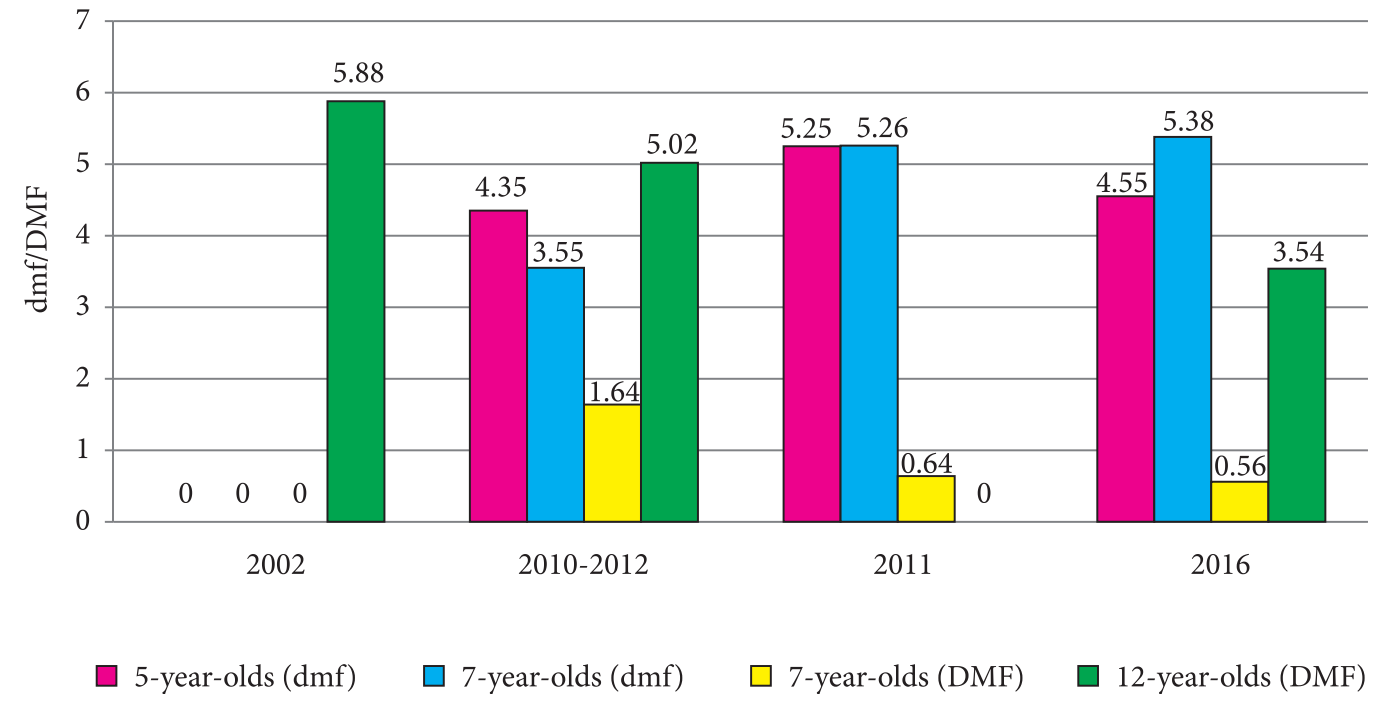

Fig. 2. Severity of caries in 5-, 7- and 12-year-old children in consecutive studies in the Małopolskie province

$89.4 \%$, which means that it decreased only by $1.1 \%$ with respect to 2011 (90.5\%) (1, 26). The mean caries severity in deciduous and permanent teeth for this age group in 2016 (5.61 and 0.59, respectively) has practically remained at the level from 2011 (5.62 and 0.56, respectively) $(1,26)$. The results of epidemiological studies on Polish 12-year-olds from 1999-2014, which is the most commonly studied age group, display a slow downward trend for caries prevalence (from 88.9 to $75.9 \%$ ) and its mean severity (from 4.0 to 2.81 ) interrupted with data from 2001 and 2003, and an increase in these parameters in the present study ( $85.4 \%$ and 3.75 , respectively) $(1,2$, $18,25,26)$ (fig. 3 and 4). An insufficient number of studies on Polish 5- and 7-year-olds precludes the determination of a caries trend for these age groups.
The comparison of caries prevalence for children from the Małopolskie province to that of the remaining provinces covered by the current monitoring study shows that the prevalence of caries in Małopolskie province is the lowest for 7- and 12-year-olds. For 5-year-olds from Małopolskie, it is comparable to the lowest figure for 5-year-olds (recorded in the Dolnośląskie province) (1). The prevalence of caries in children from Małopolskie is lower than that of the whole national population in all studied age groups (1) (fig. 5).

The comparison of the mean caries severity in children from the Małopolskie region and the remaining provinces covered by the monitoring study discussed here shows that it is the lowest in the group of 12-year-olds in our province. Caries severity in deciduous teeth ( $\mathrm{dmft}$ ) for 5 and 


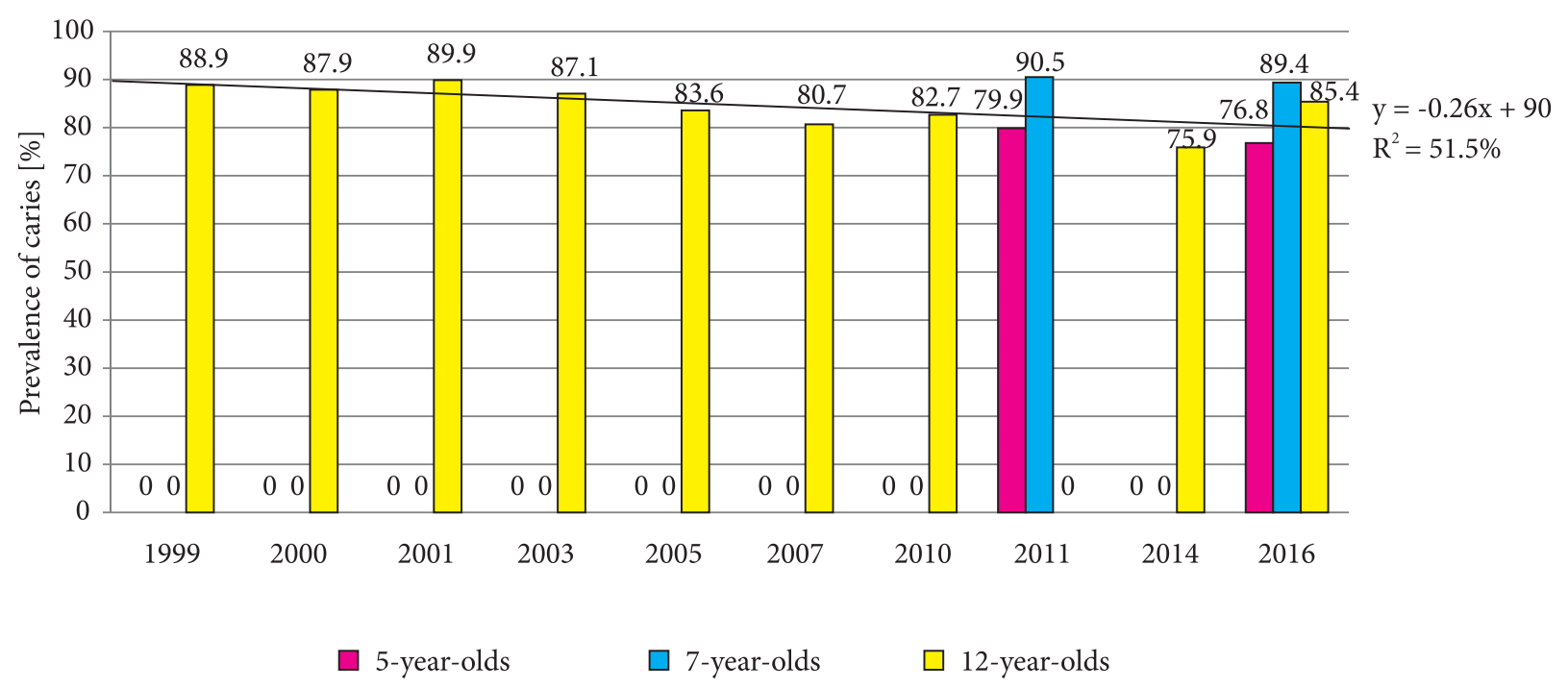

Fig. 3. Prevalence of caries in 5-, 7- and 12-year-old children in consecutive nationwide monitoring studies (data for the whole population)

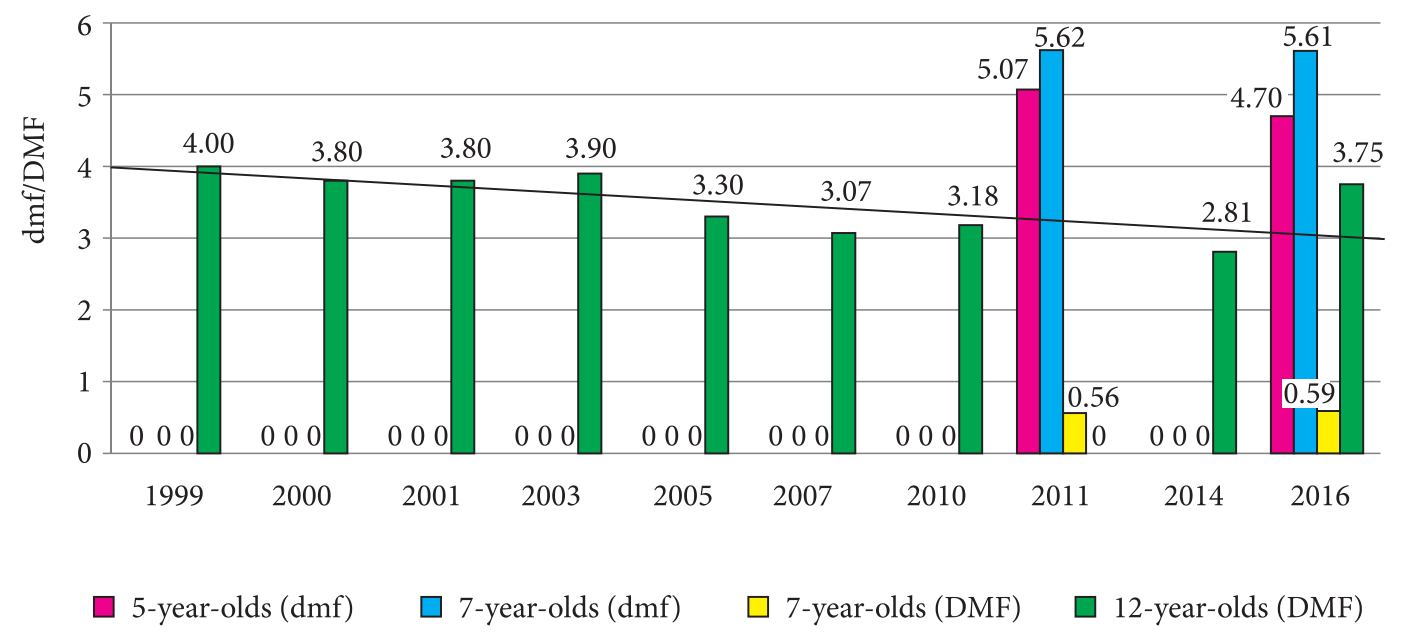

Fig. 4. Severity of caries in 5-, 7- and 12-year-old children in consecutive nationwide monitoring studies (data for the whole population)

7-year-olds is comparable with the lowest results recorded for Dolnośląskie and Lubelskie provinces, respectively (1). The severity of caries in children from Małopolskie is lower than that of the whole national population in all studied age groups (1) (fig. 6 and 7).

The prevalence and severity of caries in Polish children, including those from Małopolskie are high (even though they are lower than in other provinces), higher than in the majority of European countries $(1,2,27,28)$. A slight decrease in these parameters is noticeable in the Polish population of 5-year-olds (including from Małopolskie). In 7-year-olds they are practically unchanged (except for Małopolska, where a decrease in caries prevalence is visible). It is of particular concern that the present monitoring study has not confirmed the slow downward trend for caries indicators observed for many years in Polish 12-year-olds: they have actually increased. However, there is persistent drop in caries prevalence for the children from Małopolskie in this age group. Due to the significantly lower number of epidemiological studies conducted in Małopolskie over the years this reduction requires confirmation in further monitoring studies.

According to WHO criteria Poland is currently a country with a moderate severity of caries (DMFT for 12-year-olds in the range of 2.7-4.4). However, the result of the present monitoring study ranks Poland among countries with the highest range of DMFT: $>3(1,2,27,28)$. 
Dental caries status and trend in 5-, 7- and 12-year-old children from the Małopolskie region in comparison to the Polish...

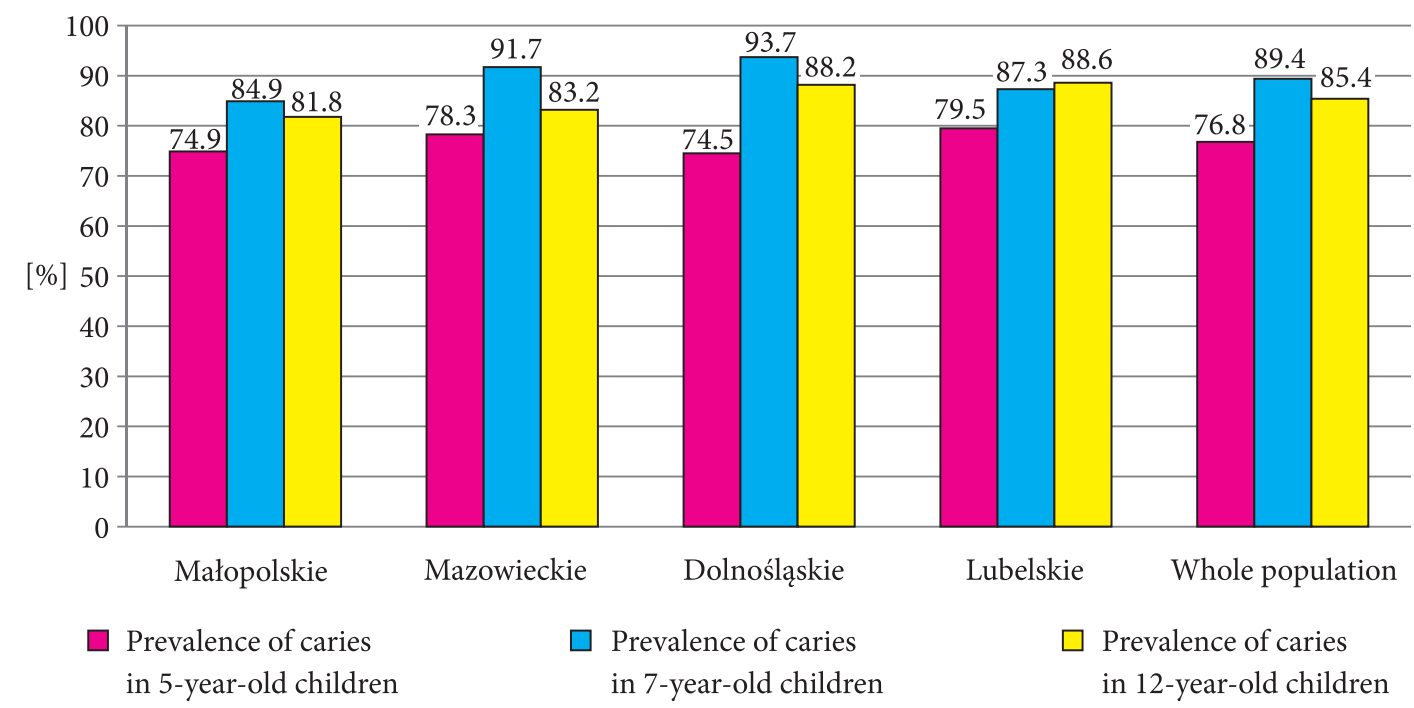

Fig. 5. Results of the current monitoring study of 2016. Prevalence of caries in 5-, 7- and 12-year-olds for different provinces and for the whole population

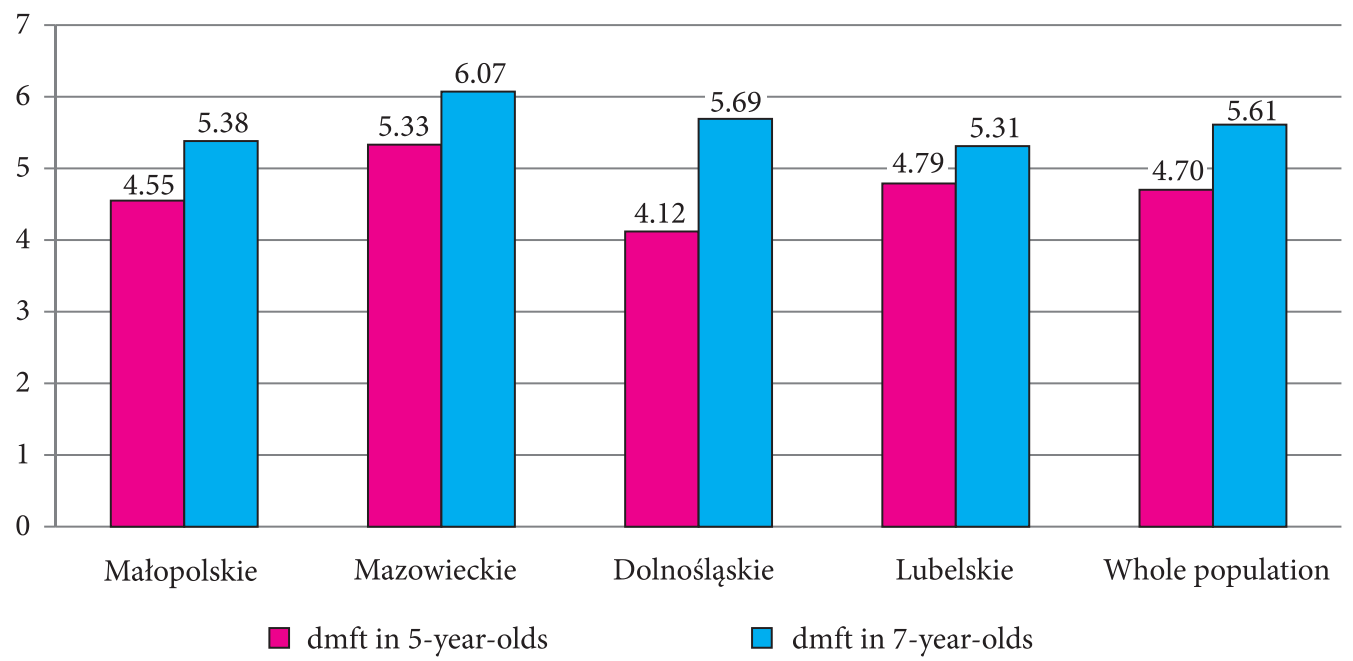

Fig. 6. Results of the current monitoring study of 2016. Mean dmft values for different provinces and the whole population of 5- and 7 -year-olds

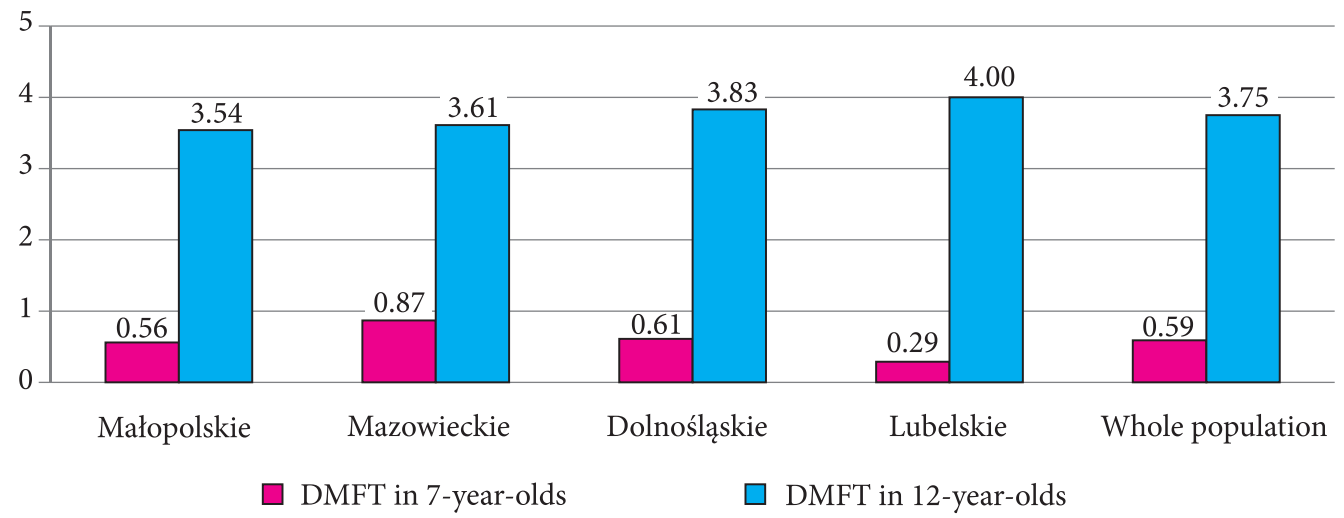

Fig. 7. Results of the current monitoring study of 2016. Mean DMFT values for different provinces and the whole population of 7- and 12-year-olds 


\section{Conclusions}

The study results presented indicate a persistently high incidence of dental caries in children from the Małopolskie province and all over Poland. There is a slight decrease in caries indicators noticeable in 5- and 7-year-old children from Małopolskie. Children aged 12 from the Małopolskie province are the only group from the whole population of this age in Poland to maintain a downward trend of caries prevalence. However, this reduction requires confirmation in further monitoring studies.
The WHO health goal established for European countries for 2020, which provides that, among other aspects, 12-year-olds should have no more than 1.5 tooth affected with caries on average, seems to be difficult to achieve in Poland (22). It is necessary to intensify measures to improve this situation through education of both children and parents, extensive preventative action and raising health awareness among patients.

\section{CONFLICT OF INTEREST}

None

\section{Correspondence}

${ }^{\star}$ Małgorzata Staszczyk Pracownia Stomatologii Dziecięcej Instytut Stomatologii Uniwersytet Jagielloński Collegium Medicum ul. Montelupich 4, 31-155 Kraków tel.: +48 (12) 424-54-20 malgosia.staszczyk@gmail.com

\section{REFERENCES}

1. Olczak-Kowalczyk D, Kaczmarek U, Bachanek T et al.: Monitoring Zdrowia Jamy Ustnej. Monitorowanie stanu zdrowia jamy ustnej populacji polskiej w latach 20162020, Minister Zdrowia, Program na lata 2016-2020. WUM, Warszawa 2017.

2. Olczak-Kowalczyk D, Szczepańska J, Kaczmarek U: Współczesna stomatologia wieku rozwojowego. Med Tour Press International, Otwock 2017: 261-274.

3. Wójcicka A, Zalewska M, Czerech E et al.: Próchnica wieku rozwojowego chorobą cywilizacyjną. Przegl Epidemiol 2012; 66: 705-711.

4. Peterson SN, Snesrud E, Liu J et al.: The dental plaque microbiome in health and disease. PLoS ONE 2013; 8: e58487.

5. Strużycka I, Wierzbicka M, Jodkowska E et al.: Stan zdrowia jamy ustnej oraz potrzeby profilaktyczno-lecznicze dzieci w wieku 6 lat w Polsce w roku 2012. Przegl Epidemiol 2014; 68: 139-142.

6. Bissar A, Schiller P, Wolff A et al.: Factors contributing to severe early childhood caries in south-west Germany. Clin Oral Investig 2014; 18: 1411-1418.

7. Bagińska J, Rodakowska E, Wilczyńska-Borawska $\mathrm{M}$ et al.: Index of clinical consequences of untreated dental caries (pufa) in primary dentition of children from north-east Poland. Adv Med Sci 2013; 21: 1-6.

8. Figueiredo MJ, de Amorin RG, Leal SC et al.: Prevalence and severity of clinical consequences of untreated dentine carious lesions in children from a deprived area of Brazil. Caries Res 2011; 45(5): 435-442.

9. Leal SC, Bronkhost EM, Fan M et al.: Untreated cavitated dentine lesions: impact on children's quality of life. Caries Res 2012; 46: 102-106.

10. Benzian $\mathrm{H}$, Monse B, Heinrich-Weltzien $\mathrm{R}$ et al.: Untreated severe dental decay: a neglected determinant of low Body Mass Index in 12-year-old Filipino children. BMC Public Health 2011; 11: 558

11. Strużycka I, Wierzbicka M, Jodkowska E et al.: Wyniki Monitoringu Stanu Zdrowia Jamy Ustnej populacji młodych dorosłych w Polsce w 2012 roku. Nowa Stomatol 2013; 18: 195-199.

12. Hobdell M, Petersen PE, Clarkson J et al.: Global Goals for oral health 2020. Int Dent J 2003; 53: 285-228.

13. Petersen PE: The World Oral Health Report 2003: continuous improvement of oral health in the $21^{\text {st }}$ century - the approach of the WHO Global Oral Health Programme. Community Dent Oral Epidemiol 2003; 31 (suppl. 1): 3-24.

14. Petersen PE, Kwan S: The $7^{\text {th }}$ WHO Global Conference on Health Promotion - towards integration of oral health. Community Dent Health 2010; 27 (suppl. 1): 129-136.

15. Petersen PE: Improvement of global oral health - the leadership role of WHO. Community Dent Health 2010; 27: 194-199.

16. Petersen PE: World Health Organization global policy for improvement of oral health - World Health Assembly 2007. Int Dent J 2008; 58: 115.

17. WHO: Oral Health Surveys. Basic methods 1997. 4th ed. WHO, Geneva 1997.

18. Wierzbicka M, Kaczmarek U: Trend choroby próchnicowej u 12-letnich dzieci na podstawie badań monitoringowych stanu zdrowia jamy ustnej. Czy polskie dzieci mają szanse na osiągnięcie narodowego i europejskiego celu zdrowia jamy ustnej? Dent Med Probl 2009; 46: 149-156. 
submitted:

16.03.2018

accepted:

6.04 .2018
19. FDI: Global goals for oral health in the year 2000. Int Dent J 1982; 32: 74-77.

20. Global caries data for 12-year-old age group WHO Oral Health Country/Area Profile Programme; http://www.whocollab.od.mah.se/exp/globalcar.html.

21. Global Oral Health - CAPP: http://www.whocollab.od.mah.se/expl/regions.html.

22. Health21. The health for all policy framework for WHO European Region. World Health Organization Regional Office in Europe. WHO, Copenhagen 1999.

23. Małkiewicz E, Wierzbicka M, Szatko F et al.: Monitoring Zdrowia Jamy Ustnej. Polska 2010. Stan zdrowia jamy ustnej i jego uwarunkowania oraz potrzeby profilaktyczno-lecznicze dzieci w wieku 6 i 12 lat oraz osób dorosłych w wieku 35-44 lat. WUM, Warszawa 2010.

24. Wierzbicka M, Szatko F, Strużycka I et al.: Monitoring Zdrowia Jamy Ustnej. Polska 2011. Stan zdrowia jamy ustnej i jego uwarunkowania oraz potrzeby profilaktyczno-lecznicze dzieci w wieku 5, 7 i 15 lat. WUM, Warszawa 2011.

25. Wyniki badań epidemiologicznych prowadzonych w ramach programu „Monitoring Zdrowia Jamy Ustnej” w 2010 roku. Ministerstwo Zdrowia, Warszawa 2010; http://www.mz.gov.pl/wp-content/uploads/2014/11/wynik_bada_mat_2010.pdf.

26. Wyniki badań epidemiologicznych prowadzonych w ramach programu „Monitoring Zdrowia Jamy Ustnej” w 2011 roku. Ministerstwo Zdrowia, Warszawa 2011; http://www.mz.gov.pl/wp-content/uploads/2014/11/monitoring_ju_2011.pdf.

27. Global caries data for 12-year-old age group WHO Oral Health Country/Area Profile programme; www.mah.se/CAPP/Country-Oral-Health- Profiles/According-toAlphabetical/Global-DMFT-for-12-year-olds-2011.

28. https://www.mah.se/CAPP/Country-Oral-Health-Profiles/EURO/.

29. WHO: Oral Health Surveys. Basic methods 2013. 5th ed. WHO, Geneva 2013.

30. Jurczak A, Kościelniak D, Gregorczyk-Maga et al.: Caries status among children residing Cracow compared with the rest of Poland. J Stoma 2014; 67: 781-799.

31. Kwapińska H, Zarzecka J, Fijał D et al.: Frekwencja i intensywność próchnicy u dzieci krakowskich szkół. Porad Stomatol 2003; 5: 18-22. 